Hydrol. Earth Syst. Sci., 17, 2233-2246, 2013

www.hydrol-earth-syst-sci.net/17/2233/2013/

doi:10.5194/hess-17-2233-2013

(C) Author(s) 2013. CC Attribution 3.0 License.

\title{
An assessment of land use change impacts on the water resources of the Mula and Mutha Rivers catchment upstream of Pune, India
}

\author{
P. D. Wagner ${ }^{1}$, S. Kumar ${ }^{2}$, and K. Schneider ${ }^{1}$ \\ ${ }^{1}$ Hydrogeography and Climatology Research Group, Institute of Geography, University of Cologne, Köln, Germany \\ ${ }^{2}$ Institute of Environment Education \& Research, Bharati Vidyapeeth University, Pune, India
}

Correspondence to: K. Schneider (karl.schneider@uni-koeln.de)

Received: 21 December 2012 - Published in Hydrol. Earth Syst. Sci. Discuss.: 11 February 2013

Revised: 16 May 2013 - Accepted: 19 May 2013 - Published: 19 June 2013

\begin{abstract}
Land use changes are altering the hydrologic system and have potentially large impacts on water resources. Rapid socio-economic development drives land use change. This is particularly true in the case of the rapidly developing city of Pune, India. The present study aims at analyzing past land use changes between 1989 and 2009 and their impacts on the water balance in the Mula and Mutha Rivers catchment upstream of Pune. Land use changes were identified from three Rivers catchment multitemporal land use classifications for the cropping years 1989/1990, 2000/2001, and 2009/2010. The hydrologic model SWAT (Soil and Water Assessment Tool) was used to assess impacts on runoff and evapotranspiration. Two model runs were performed and compared using the land use classifications of 1989/1990 and 2009/2010. The main land use changes were identified as an increase of urban area from $5.1 \%$ to $10.1 \%$ and cropland from $9.7 \%$ to $13.5 \%$ of the catchment area during the $20 \mathrm{yr}$ period. Urbanization was mainly observed in the eastern part and conversion to cropland in the mid-northern part of the catchment. At the catchment scale we found that the impacts of these land use changes on the water balance cancel each other out. However, at the sub-basin scale urbanization led to an increase of the water yield by up to $7.6 \%$, and a similar decrease of evapotranspiration, whereas the increase of cropland resulted in an increase of evapotranspiration by up to $5.9 \%$.
\end{abstract}

\section{Introduction}

Land use changes have potentially large impacts on water resources (Stonestrom et al., 2009). Rapid socio-economic development drives land use changes, which include changes of land use classes, e.g., conversion of cropland to urban area due to urbanization, as well as changes within classes such as a change of crops or crop rotations. Particularly in regions where water availability is limited, land use changes could result in an increase of water scarcity and thus contribute to a deterioration of living conditions. DeFries and Eshleman (2004) underline the importance of understanding the impact of land use change on water resources, which they identify as a key research topic for the decades ahead.

In order to assess past land use changes, satellite images provide valuable spatially distributed information. Historic multispectral satellite images can be used to produce past land use classifications. However, in the absence of historic ground truth data, different methods and data (e.g., historic topographic or land use maps) are employed to derive accurate past classifications (e.g., Miller et al., 2002; Seeber et al., 2010). These classifications are superior to commonly used freely available, global data sets (e.g., Hansen et al., 1998), as they provide a higher spatial resolution $(30 \mathrm{~m})$ and often have a higher level of detail with regard to the number of distinguished classes. Each land use classification is representative of the date of the satellite image and the phenology of the plants at this time in the year (Jensen, 2007). Particularly in regions with a high temporal variability in temperature (e.g., temperate and continental climates) or precipitation (e.g., tropical wet and dry climates), the date of the satellite imagery has a pronounced impact on the identifiable and 
distinguishable land use classes. In order to derive a classification which is representative of the whole year, several land use classifications from different times in the year can be combined to produce one multitemporal land use classification (e.g., Villarreal et al., 2011; Yuan et al., 2005). By this means, the intra-annual differences are minimized. Thus, a series of such multitemporal land use classifications can be analyzed to identify the inter-annual or, in the present case, inter-decadal changes over a past period of time.

In order to assess impacts of land use change on water resources hydrologic models are typically employed, e.g., HBV (Bergström and Forsman, 1973; e.g., Ashagrie et al., 2006), MIKE-SHE (Refsgaard and Storm, 1995; e.g., Im et al., 2009), SWAT, (Arnold et al., 1998; e.g., Fohrer et al., 2001), or WaSiM-ETH (Schulla, 1997; e.g., Niehoff et al., 2002). Models are particularly useful, as they can assess past as well as possible future impacts (using land use scenarios). Huisman et al. (2009) employed an ensemble of ten hydrologic models (the four previously named and six other models) to assess the impact of land use change scenarios, which resulted in a range of predictions that were generally in agreement with respect to the direction of the impact on discharge. The Soil and Water Assessment Tool (SWAT, Arnold et al., 1998) has proven its suitability for hydrologic impact studies (Gassman et al., 2007) and furthermore under conditions of limited data availability (Ndomba et al., 2008; Stehr et al., 2008). Hence, it is a suitable model to study the impact of land use changes on water resources in India.

Investigations of the effects of past land use changes on water availability have been carried out in many regional studies worldwide (e.g., Ghaffari et al., 2010: Iran; Im et al., 2009: Korea; Li et al., 2009: China; Miller et al., 2002: USA). Furthermore, impacts of land use scenarios on the water resources have been analyzed in many other regional studies e.g., in Germany (Klöcking and Haberlandt, 2002; Barthel et al., 2012), Canada (Wijesekara et al., 2012), Ethiopia (Legesse et al., 2003), and Kenya (Mango et al., 2011).

Several investigations of land use changes and land use change impacts have been carried out in India. Chauhan and Nayak (2005) reported that industrial development and population pressure in Hazira, Gujarat, led to an increase of builtup area and a decrease in forest and agricultural areas between 1970 and 2002. Jayakumar and Arockiasamy (2003) have found an increase of cropland and a decrease of grassland and shrubland in a study on a part of the Eastern Ghats in South India. Deforestation between 1973 and 1995 was reported in a study on the southern part of the Western Ghats by Jha et al. (2000). Similarly, a study about Indian Himalayan catchments by Sharma et al. (2007) found a decrease of natural forest and an increase of agricultural land.

Impacts of land use change on the water resources in India were mainly assessed by using scenario analysis. Particularly, agricultural management practices are a focus of the research in India: Garg et al. $(2012 b, c)$ found that agricultural water interventions had a pronounced impact on water resources, Sharma et al. (2001) employed land use and land management measures that decreased the water yield significantly, and Behera and Panda (2006) identified critical subwatersheds and tested best management practices to minimize sediment and nutrient loads. Mishra et al. (2007) analyzed the effects of land use on runoff and sediment yield to prioritize the construction of structural water management measures. Wilk and Hughes (2002) conducted a study in South India employing several land use scenarios, and found that only the extreme and very unlikely scenarios had a pronounced impact on runoff. The largest increases of runoff were found when converting forest and savanna to agriculture, whereas the largest decrease of runoff resulted from a conversion to forest in this study. Further Indian studies focus on the impact of land use change on groundwater (e.g., Khan et al., 2011; Ramesh, 2001; Singh, 2001).

A comprehensive assessment of land use change impacts on water resources in an area with seasonally limited water availability, and which is subject to rapid socio-economic development and population growth, will provide an exemplary view on the local impacts of major recent developments in India. The city of Pune has experienced such rapid socio-economic development and population growth in recent decades. In Pune district, where Pune city is the largest urban and economic agglomeration, population has increased by more than $30 \%$ per decade between 1991 and 2011 (Government of India, 2011). It is the aim of this study to (i) assess the land use changes between 1989/1990 and 2009/2010, and (ii) analyze the impacts of these changes on the long-term water balance components in the Mula and Mutha Rivers catchment upstream of the city of Pune.

\section{Materials and methods}

\subsection{Study area}

The meso-scale catchment of the Mula and the Mutha Rivers $\left(2036 \mathrm{~km}^{2}\right)$ is located in the Western Ghats upstream of the city of Pune, India $\left(18.53^{\circ} \mathrm{N}, 73.85^{\circ} \mathrm{E}\right.$; Fig. 1). It is a subbasin and source area of the Krishna River, which drains towards the east and into the Bay of Bengal. Its elevation ranges from $550 \mathrm{~m}$ in Pune up to $1300 \mathrm{~m}$ a.s.l. on the top ridges in the Western Ghats. The catchment has a tropical wet and dry climate, which is characterized by seasonal rainfall from June to October, and low annual temperature variations with an annual mean of $25^{\circ} \mathrm{C}$ at the catchment outlet in Pune. Annual rainfall amounts decrease from approximately $3500 \mathrm{~mm} \mathrm{a}^{-1}$ in the western part of the catchment to $750 \mathrm{~mm} \mathrm{a}^{-1}$ in the eastern part of the catchment (Gadgil, 2002; Gunnell, 1997). Land use is dominated by semi-natural vegetation, with forests mainly on the higher elevations in the west, whereas shrubland and grassland occupy lower elevations. Cropland is found mainly in proximity to rivers and reservoirs, and is dominated by small fields ( $<1 \mathrm{ha})$ with 


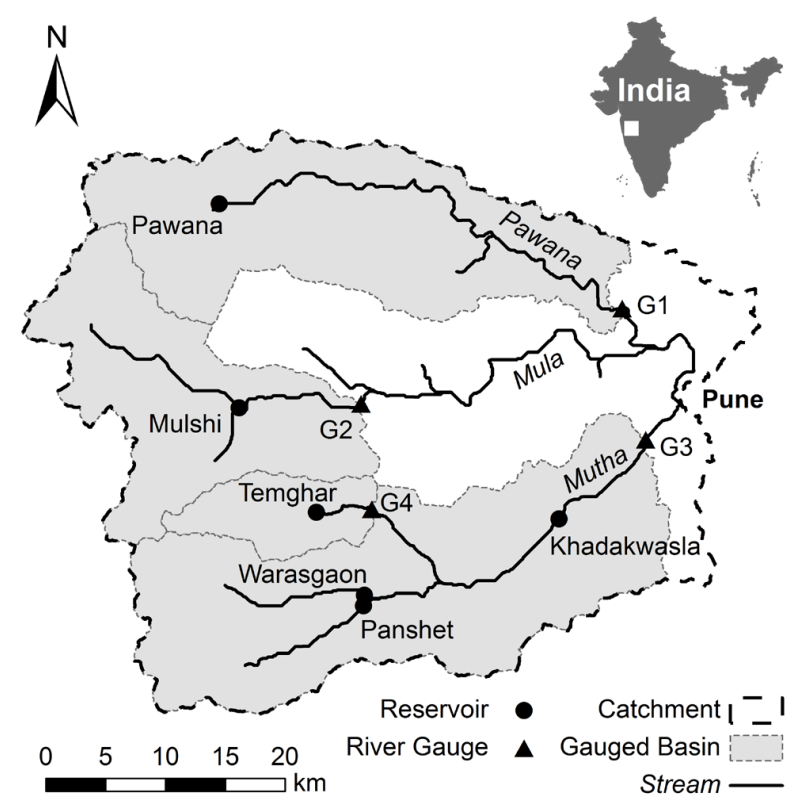

Fig. 1. Mula-Mutha catchment with the locations of river gauges and reservoirs.

rain-fed agriculture during the monsoon season and irrigation during the dry season. Typically two crops per year are harvested, a Kharif (June-October) and a Rabi (NovemberMarch) crop. Urban area is mainly found in the eastern part of the catchment, where the city of Pune and its surrounding settlements are located. Six major reservoirs are located within the study area (Fig. 1), which indicate the catchment's importance for downstream water users and reservoirs (Garg et al., 2012a), such as the large Ujjani reservoir about $100 \mathrm{~km}$ downstream of Pune. Furthermore, water is diverted from the catchment to the west, as the largest reservoir in the catchment (Mulshi) serves for power generation for the city of Mumbai (Wagner et al., 2012).

\subsection{Assessment of land use changes}

The study area experienced rapid socio-economic development and population growth during the two most recent decades. In order to analyze the land use changes caused by this development, we produced three multitemporal land use classifications for the cropping years 1989/1990, 2000/2001, and 2009/2010. These classifications are based on multispectral satellite data. Different sensors were used to cover the $20 \mathrm{yr}$ time span of this study. The classifications are based on Landsat 5 TM data for 1989/1990, on Landsat 7 ETM+ data for 2000/2001, and on IRS-P6 (Resourcesat-1) LISS-III data for 2009/2010. All sensors have a similar spatial resolution of $30 \mathrm{~m}(\mathrm{TM} / \mathrm{ETM}+)$ or $23.5 \mathrm{~m}$ (LISS-III), and have bands in the visible, the near-infrared, and the shortwave infrared region (Landsat TM/ETM+: 6 bands; LISS-III: 4 bands). Furthermore, all of these satellite sensors are commonly used to
Table 1. Quality of the land use classifications in 2009/2010 assessed by using mapped ground truth data.

\begin{tabular}{llll}
\hline \multirow{2}{*}{ Indicator } & Classes & \multicolumn{2}{c}{ LISS-III Scene } \\
\cline { 3 - 4 } & & 30 Nov 2009 & 6 Mar 2010 \\
\hline Overall & Combined agricultural classes & $79.1 \%$ & $82.9 \%$ \\
accuracy & Distinguished agricultural classes & $65.6 \%$ & $58.8 \%$ \\
\hline \multirow{2}{*}{ User's } & Forest & $78.6 \%$ & $91.9 \%$ \\
accuracy & Shrubland & $45.4 \%$ & $70.8 \%$ \\
& Grassland & $68.9 \%$ & $52.7 \%$ \\
& Bare soil & $41.0 \%$ & $43.7 \%$ \\
& Mixed cropland & $27.4 \%$ & $41.8 \%$ \\
& Rice 2009/Wheat 2010 & $86.4 \%$ & $31.5 \%$ \\
& Sugarcane & $92.4 \%$ & $51.0 \%$ \\
& Urban & $89.1 \%$ & $91.1 \%$ \\
\hline
\end{tabular}

produce land use classifications (e.g., LISS-III: Jayakumar and Arockiasamy, 2003; Saha et al., 2005; TM: Seeber et al., 2010; Villarreal et al., 2011; ETM+: Peiman, 2011; Yuan et al., 2005). To achieve a good representation of the cropping year at least two images corresponding to the two cropping seasons were used for each multitemporal classification. Due to the absence of mapped ground truth data for the past, two different methodologies were applied for the current and the historic land use classifications, respectively.

\subsubsection{Current land use classification}

For the current land use classification, ground truth data was mapped at three test sites in and near the study area. Field surveys were carried out during each of the two cropping seasons; one in September and October 2009 and another one in February and March 2010. Rice, wheat and sugarcane were the most important crops. Based on the field survey data, we confirmed the expected crop rotation of rice in rainy season and wheat in dry season. Sugarcane is a perennial plant. Due to their diversity and small-scale patchiness, the other agricultural land use types were combined into a mixed cropland class. The next available cloud-free LISS-III satellite images corresponding to the two field surveys (30 November 2009, 6 March 2010) were used to produce two land use classifications. The satellite images were geometrically corrected using ground truth points. A stratified knowledgebased approach, employing a maximum likelihood classifier, was applied as follows: for agricultural land use thresholds in terms of elevation $(<800 \mathrm{~m})$ and slope $(<10 \%)$ were set, as cropland is typically located in the valleys and in proximity to rivers. Pixels classified as cropland that exceeded these thresholds were labeled as grassland. A majority analysis on a moving $3 \times 3$ raster window was applied to remove misclassified, spatially singular pixels within homogenous areas (Wagner et al., 2011). Water bodies were defined using a threshold value for the near-infrared band. The ground truth data were used to define the training areas for the classification and for validation of the classification results. Both classifications showed reasonable accuracies (Table 1). 
Table 2. Applied rules to derive a multitemporal land use classification for the cropping year 2009/2010.

\begin{tabular}{ll}
\hline Class Combinations & Multitemporal Result \\
\hline Forest - Shrubland & Forest \\
Forest - Grassland & Shrubland \\
Shrubland - Grassland & Shrubland \\
Grassland - Bare soil & Grassland \\
Agricultural class - Bare soil & Agricultural class \\
Urban high density - Urban low density & Urban high density \\
Mixed cropland - Sugar or Rice & Sugar or Rice \\
Sugar or Rice of 2009 - Sugar or Wheat of 2010 & Sugar or Rice of 2009 \\
Mixed cropland 2009 - Wheat 2010 & Mixed Cropland \\
Equal land use & Equal land use \\
No rules apply & New classification using both scenes \\
\hline
\end{tabular}

In order to derive a single land use map that is representative for the whole cropping year, the two classifications were combined by using the rules shown in Table 2 . For the combination of two semi-natural classes priority was given to the class with a higher percentage of trees (e.g., if a pixel was classified as forest in one of the classifications and as shrubland in the other one, the pixel was assigned as forest in the combined classification). As bare soil is a temporary land use, a combination of cropland and bare soil, or grassland and bare soil was defined as cropland or grassland, respectively. In the cases of a contradictory combination of sugarcane, rice, and wheat, the 2009 land uses were given priority over the 2010 land uses, as higher user accuracies were achieved for these classes in the 2009 land use classification (Table 1). Areas were reclassified, where both classifications showed different uses and where none of the rules described above were applicable. For this reclassification both scenes and homogeneous ground truth information for 2009 and 2010 were used. Water areas were taken from the November classification, corresponding to the maximum water level in the reservoirs. By this multitemporal assessment a classification was derived that is suitable to represent the whole cropping year.

Reasonable accuracy of the classification was also indicated by a comparison with the most recent agricultural statistics (cropping year 2007/2008) available from the Department of Agriculture in Pune. Statistics are provided for each season (Kharif and Rabi) and for the perennial plant sugarcane. An administrative area (the subdistrict Mulshi) within the catchment that is about half of its size was used for this comparison. As compared to the statistics the classification showed less sugarcane area $(-12 \%)$, and less total cropping area in Kharif season $(-39 \%)$, and in Rabi season $(-8 \%)$. Reasons for the pronounced difference in Kharif season might be: (i) the quality of the land use statistics, which are based on sampling methods, (ii) the rice area in the 2009 classification might be underestimated, as the satellite image was taken in November, when some rice fields were already harvested, and (iii) the compared data is based on different years. However, the good overall accuracy $(79.1 \%)$ of the land use classification in 2009 makes it seem unlikely that the total agricultural area is underestimated by $39 \%$ in Kharif season. The combination of the two land use classifications (2009 and 2010), which both showed reasonable accuracies in the validation with mapped ground truth (Table 1), gives further confidence in the quality of the derived multitemporal classification.

\subsubsection{Historic land use classifications}

For the historic land use classifications mapped ground truth data was not available. Thus training areas for the forest, shrubland, grassland, and urban area classes were defined using topographic maps and satellite images. The topographic maps in this area date back to 1962-1980, so that a training area was only defined as forest, shrubland, grassland or urban area, if topographic map and satellite image showed consistent information. In addition, the regional knowledge of typical locations for forest (in the western part of the catchment), shrubland (on the foot of the hills), and grassland (in the valleys or on the plain mountain plateaus) in combination with Normalized Difference Vegetation Index (NDVI) values was used. Cropland was identified from the satellite image, where field structures were clearly observable. Current agricultural fields (high NDVI) were distinguished from harvested agricultural fields (low NDVI). A third, intermediate agricultural class was defined, which had an intermediate NDVI value. Clouds and cloud shadows were visually identified and masked.

Hence, the images were geometrically corrected using the previously corrected LISS-III satellite images. Subsequently, the same stratified knowledge-based approach (elevation and slope thresholds, majority analysis) with a maximum likelihood classifier was employed as in the classification of the current land use classifications. The derived historic classifications were evaluated using the training areas which were defined above. Table 3 shows that all six classifications had a very good overall accuracy (92.4-98.6\%) and good or better 
Table 3. Quality of the land use classifications in 1989/1990 and 2000/2001.

\begin{tabular}{|c|c|c|c|c|c|c|c|}
\hline \multirow[b]{2}{*}{ Indicator } & \multirow[b]{2}{*}{ Classes } & \multicolumn{3}{|c|}{ Landsat $5 \mathrm{TM}$} & \multicolumn{3}{|c|}{ Landsat 7 ETM+ } \\
\hline & & 25 Oct 1989 & 12 Dec 1989 & 2 Mar 1990 & 15 Oct 2000 & 19 Jan 2001 & 24 Mar 2001 \\
\hline Overall accuracy & & $95.9 \%$ & $92.4 \%$ & $93.0 \%$ & $98.6 \%$ & $96.7 \%$ & $96.8 \%$ \\
\hline \multirow[t]{7}{*}{ User's accuracy } & Forest & $98.7 \%$ & $97.7 \%$ & $98.4 \%$ & $98.7 \%$ & $99.1 \%$ & $99.3 \%$ \\
\hline & Shrubland & $82.2 \%$ & $74.0 \%$ & $74.0 \%$ & $95.9 \%$ & $81.9 \%$ & $82.3 \%$ \\
\hline & Grassland & $98.1 \%$ & $95.9 \%$ & $94.8 \%$ & $99.7 \%$ & $97.7 \%$ & $97.2 \%$ \\
\hline & Cropland 1, current & $97.6 \%$ & $98.4 \%$ & $98.6 \%$ & $95.5 \%$ & $96.3 \%$ & $97.1 \%$ \\
\hline & Cropland 2, harvested & $99.5 \%$ & $74.6 \%$ & $94.1 \%$ & $99.7 \%$ & $97.9 \%$ & $94.2 \%$ \\
\hline & Cropland 3 , intermediate & $79.7 \%$ & $97.9 \%$ & $77.2 \%$ & $96.3 \%$ & $91.9 \%$ & $99.0 \%$ \\
\hline & Urban & $99.5 \%$ & $87.0 \%$ & $99.5 \%$ & $100.0 \%$ & $99.2 \%$ & $99.6 \%$ \\
\hline
\end{tabular}

Table 4. Applied rules to derive multitemporal land use classifications for the cropping years 1989/1990 and 2000/2001.

\begin{tabular}{ll}
\hline Class Combinations & Multitemporal Result \\
\hline Any two agricultural classes in at least two scenes & Agricultural class \\
Equal land use in two or three scenes & Dominant land use \\
No rules apply & New classification using all scenes \\
\hline
\end{tabular}

user accuracies (Story and Congalton, 1986) for each class (74.0-100.0\%). This assessment indicates that the defined main land use classes were accurately distinguished.

To reduce uncertainty that may result from missing mapped ground truth data an additional third satellite image was used, so that the multitemporal classifications for the cropping years 1989/1990, and 2000/2001 were derived by using three classifications per cropping year (25 October 1989, 12 December 1989, 2 March 1990, and 15 October 2000, 19 January 2001, 24 March 2001). Water areas were taken from the October classifications, which correspond to the maximum water level in the reservoirs. In all other cases, the dominant land use was used for the multitemporal classification (majority approach). If all classifications showed a different land use, the pixel was reclassified using all bands of all three satellite scenes (Table 4). The three agricultural classes were combined to one general class.

In order to distinguish the major crops (sugarcane, crop rotation rice-wheat), from the general agricultural class in the historic land use classification, we used (i) agricultural statistics to derive the percentage of total cropped area for these crops, and (ii) spectral signatures of rice and sugarcane to derive the spatial distribution of these percentages.

i. While the selection of crops is a farmer's choice, the agricultural statistics for the district of Pune indicate that both sugarcane and rice percentages of the total agricultural area increased between 1988/1989 and $2007 / 2008$. A linear regression analysis was used to derive the mean rate of these significant linear changes ( $p$ values $<0.01$ ). It was assumed that both sugarcane and rice percentages of the total agricultural area in the catchment have undergone the same linear change, as the catchment is situated within the district of Pune.
Thus the change, as indicated by the regression, was applied to the percentages of both sugarcane and rice fields in the land use classification of 2009/2010 (sugarcane: $9.8 \%$, rice: $55.6 \%$ ) to calculate the percentages for the classifications in 2000/2001 $(7.3 \%, 51.4 \%)$, and $1989 / 1990(4.3 \%, 46.2 \%)$.

ii. The spectral information divergence method (Du et al., 2004) was used to identify which agricultural pixels are most similar to measured plant spectra. These spectra were taken during the field survey in September and October 2009. To apply the spectral information divergence method, the satellite images taken in October 1989 and 2000 were atmospherically corrected using the MODTRAN4-based FLAASH module in ENVI Version 4.8 (Matthew et al., 2000). Hence, Landsat bands 1 to 4 in the visible and shortwave infrared region were used to apply the method as follows: a threshold value for each spectrum was set, which defines the minimum allowable variation between the pixel vector and the spectrum vector. If the threshold was exceeded, the pixel was not classified and thus remained mixed cropland. Threshold values used in the spectral information divergence method were set, so that the derived percentages of the total cropped area for sugarcane and rice fields in the final classification were equal to the percentages calculated from the agricultural statistics. The method provides a reasonable spatial distribution of rice fields in the mountainous, western part of the catchment, and of sugarcane fields in the lower regions, especially downstream of Pune. A majority analysis was applied to the newly distinguished crops to derive the final multitemporal land use classifications for the years $1989 / 1990$ and 2000/2001. 


\subsection{Assessment of land use change impacts on} water resources

In this study, the Soil and Water Assessment Tool (SWAT, Arnold et al., 1998) was used to assess the impact of land use change on water resources. In previous studies, we showed the suitability of SWAT to model the water fluxes in the Mula and Mutha Rivers catchment (Wagner et al., 2011, 2012). Since details of the model setup and parameterization are available in the published previous studies, we will only present the following brief summary of data inputs and model parameterization.

A digital elevation model (DEM) with a spatial resolution of $30 \mathrm{~m}$ was derived from ASTER satellite data. The spatial distribution of soils was taken from the digital Soil Map of the World (FAO, 2003). Soil parameterization was partly adapted from a modeling study of the region by Immerzeel et al. (2008), and partly taken from the FAO (2003) database. Measured weather data for the period from 1988 to 2008 was used. The full data set of measured maximum and minimum temperature, humidity, solar radiation, and wind speed data was only available at the IMD weather station in Pune (ID $430630,18.53^{\circ} \mathrm{N}, 73.85^{\circ} \mathrm{E}, 559 \mathrm{~m}$ a.s.l.). Missing values were filled. To account for temperature differences in the catchment, temperature values were adjusted using adiabatic temperature gradients. The spatially distributed temperature records and the specific humidity measured at the weather station in Pune were employed to calculate spatially distributed relative humidity (Wagner et al., 2011). Rainfall data was available from 16 gauges within or near the study area. A thorough analysis of the data and of different interpolation schemes was carried out. Regression kriging using satellite data of the Tropical Rainfall Measuring Mission (TRMM) was found to be a suitable approach and hence used in this study to interpolate rainfall to a $1 \mathrm{~km}^{2}$ grid (Wagner et al., 2012). Two models were built for the land use classification of 1989/1990 and 2009/2010, respectively. In order to account for the two main cropping seasons in the region, crop rotations were set up as follows: for the rice fields, the typical crop rotation (as observed in the field survey) of growing rice in the Kharif season (June to October) and wheat in the Rabi season (November to March) was implemented. Sugarcane is cultivated year-round. Mixed cropland is simulated as a mixture of the general crop classes in SWAT (AGRL, AGRR; Neitsch et al., 2010). The bare soil class was modeled as mixed cropland (50\%) and grassland (50\%), as it is composed of harvested fields as well as non-agricultural bare soils. Irrigation schemes for all of these crops were set up (Wagner et al., 2011). For the six major dams in the catchment (Fig. 1), a management scheme was developed, which is based on general management rules allowing for water storage in the rainy season and water release in the dry season. Water abstraction at the Mulshi and Khadakwasla dams is incorporated into the model, based on a constant monthly abstraction rate that was estimated using downstream river gauge measurements. Please refer to Wagner et al. (2011, 2012) for further information on the model setup.

SWAT input parameters were not specifically optimized with regard to stream flow predictions. They were either (a) estimated from readily available GIS databases, or (b) were chosen from the literature for the given site condition, or (c) default model parameters were selected. Tuning the model to one specific condition may introduce a bias when the model is applied in other conditions (Kirchner, 2006). A land usespecific calibration was therefore not applied, as it might bias or mask the impact of two different land use inputs on the water balance. A detailed overview of the model parameterization and a thorough validation of the model are given in Wagner et al. (2012). For the present study, Nash-Sutcliffe efficiency (NSE, Nash and Sutcliffe, 1970; G1: 0.68 to 0.69, G4: $0.67)$ and percentage bias (G1: $+4 \%$ to $+5 \%, \mathrm{G} 4:+24 \%)$ indicate good performances at the river gauges G1 and G4 (Fig. 1) for both land use classifications. The model was evaluated using the available daily discharge data during rainy seasons between 2001 and 2007. Model performance in the highly managed sub-catchments G2 and G3 depends strongly on dam management.

For the analysis of land use change impacts on the water balance components, two model runs were performed with measured weather data from 1988 to 2008 using the land use classifications for $1989 / 1990$ and for $2009 / 2010$, respectively. This delta approach is frequently used to assess the impact of land use changes (e.g., Ghaffari et al., 2010; Im et al., 2009; Miller et al., 2002). Only model parameters that were defined by the land use map were different in the two model setups. Therefore, the number of hydrologic response units (HRUs), which are unique land use soil - slope class combinations, differed in the two model setups. The 2009/2010 model had more HRUs (917) than the 1989/1990 model (640), because the 2009/2010 land use classification had a higher level of detail (high-density urban area and bare soil class). Furthermore, one of the major dams that became operational in the year 2000, was not included in the model run for the 1989/1990 land use map and was included as being operational during the entire $21 \mathrm{yr}$ model run for the 2009/2010 land use. The first year of the model runs was used as a model spin-up phase. Thus, analysis of water resources was carried out by comparing the $20 \mathrm{yr}$ average water balance components using the model results for the two different land use classifications. Consequently, effects of climate variability do not affect our analysis, which is focused on differences of the average water balance components in the two model runs. 


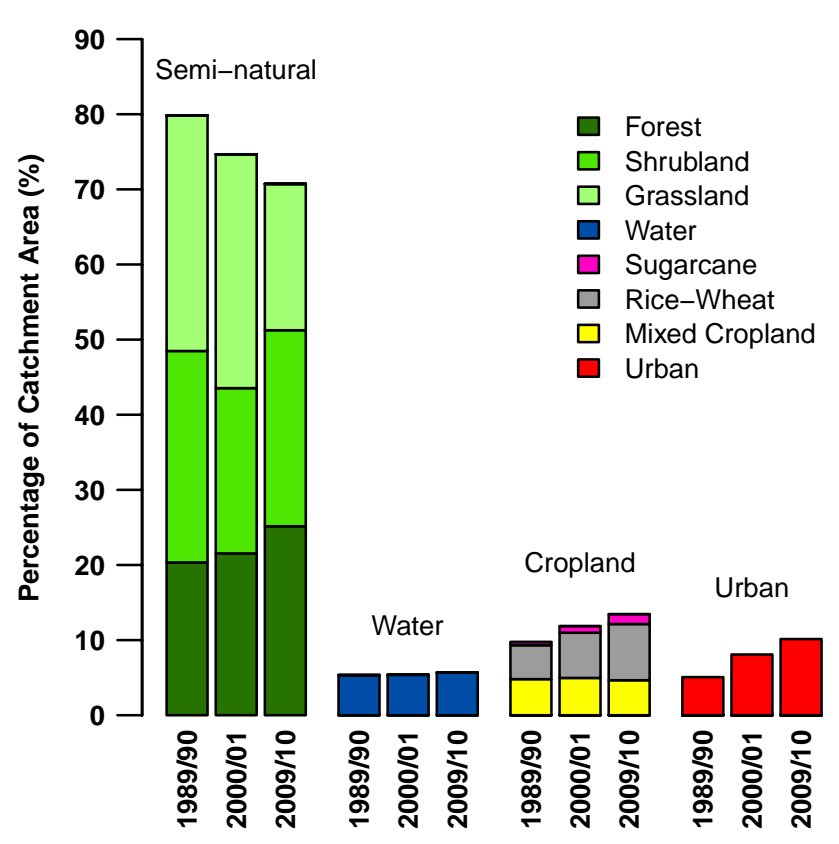

Fig. 2. Percentage changes of land use classes between 1989/1990 and 2009/2010. Percentages are shown as bars for each land use classification. Forest, shrubland, and grassland are combined to one semi-natural land use bar. Sugarcane, the rice-wheat crop rotation, and the mixed cropland class are shown as one agricultural land use bar.

\section{Results}

\subsection{Land use change analysis}

The major changes within the last $20 \mathrm{yr}$ as indicated by the three land use maps (see Figs. A1, A2, and A3 in the Appendix) are changes from semi-natural vegetation to cropland and urban area. Thus the semi-natural vegetation classes of forest, shrubland and grassland are combined in Fig. 2. The area of semi-natural vegetation decreased from $79.8 \%$ in $1989 / 1990$ to $74.7 \%$ in $2000 / 2001$ and $70.7 \%$ in $2009 / 2010$ (Fig. 2). Due to urbanization and industrial development, the percentage of built-up land has increased in the region (5.1\% in $1989 / 1990,8.1 \%$ in $2000 / 2001$, and $10.1 \%$ in 2009/2010). Also the agricultural area has increased from $9.7 \%$ to $13.5 \%$ between $1989 / 1990$ and 2009/2010. The district statistics do not show an increase in agricultural area, but in contrast show a decrease of total cropland by $11 \%$ between 1988/1989 and 2007/2008. This discrepancy may be due to the fact that the study area composes only $13 \%$ of the district so that different trends are possible and not contradictory. The percentage of catchment area covered by water increases slightly between 1989/1990 (5.3\%) and 2009/2010 $(5.7 \%)$.

The land use classification of $1989 / 1990$ was compared to the land use classification of 2009/2010 in order to identify the regions where the main changes between 1989 and

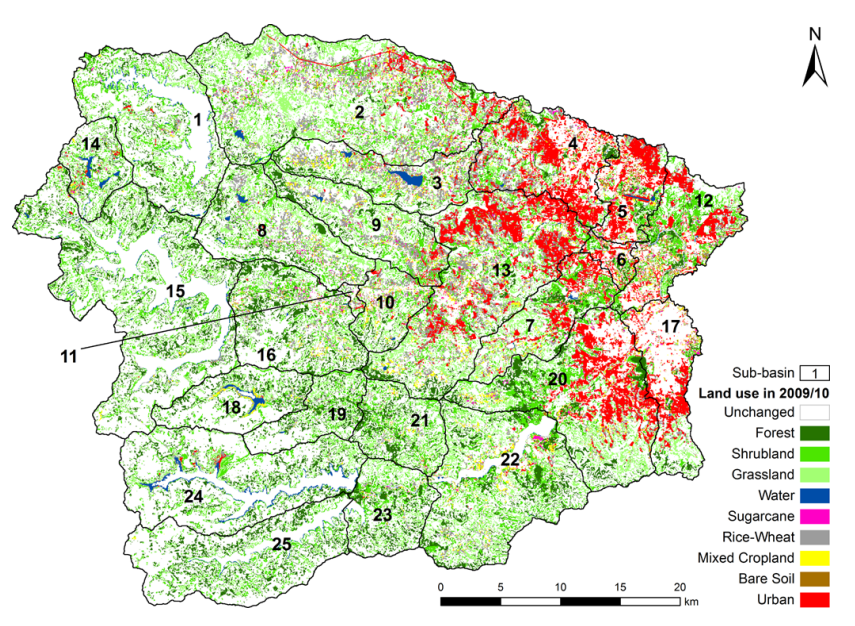

Fig. 3. Current land use $(2009 / 2010)$ of the areas that have been changed between 1989/1990 and 2009/2010. Unchanged areas (57.0\% of the catchment) are shown in white.

2009 occurred. Figure 3 shows the changed and unchanged areas $(43.0 \%$ and $57.0 \%$ of the catchment area, respectively), in which the changed areas depict the land use of the 2009/2010 classification. Only the major changes are shown, i.e., changes within the agricultural classes or within the urban land use classes were considered as unchanged areas. Major increases of urban area occurred on the fringes and to the northwest of the city of Pune. The growth towards the northwest follows the newly built National Highway 4 to Mumbai (clearly observable as a red line in subbasin 2, Fig. 3) and covers the rapidly developing area of Pimpri Chinchwad. Mainly grassland $(72.8 \%)$ and cropland $(21.7 \%)$ are converted to urban area (Table 5). It should be noted that past growth of the city of Pune to the east and northeast is not reflected in this study, as these areas are not part of the catchment. The map indicates major changes to agricultural area in the valleys of the northern part of the catchment (sub-basins 2, 3, 4, 8, 9, 13). Mainly grassland $(70.8 \%)$ and shrubland $(17.1 \%)$ are converted to serve these purposes (Table 5). The slight increase of catchment area covered by water (Fig. 2) can be attributed to the construction of the Kasarsai reservoir in 1995 (sub-basin 3 in Fig. 3) and the expansion of the Temghar dam reservoir in the year 2000 (sub-basin 18).

Variations between the semi-natural classes (Fig. 2) should not be overinterpreted, as these classes overlap and are therefore hard to distinguish. The analysis of the changes by land use class between 1989/1990 and 2009/2010 shows that the land use changes of semi-natural classes are mainly intra-class changes (Table 5). The main percentage of the area that was changed to forest, shrubland, or grassland in $2009 / 2010$ was under semi-natural land use in $1989 / 1990$ (forest: $92.1 \%$, shrubland: $84.3 \%$, grassland: $83.5 \%$; Table 5). Thus, even though the changes to semi-natural classes in $2009 / 2010$ account for $27.3 \%$ of the catchment area, they 
Table 5. Information on the changed areas (43.0\% of the catchment): (i) distribution of former land use (1989/1990) of areas converted into the current land use (2009/2010) for each class. (ii) Area changed into the current land use class as percentage of the catchment area. (iii) Net change per land use class between 1989/1990 and 2009/2010 as percentage of the catchment area (2009/2010 bare soil class was split and added to cropland and grassland for this assessment).

\begin{tabular}{|c|c|c|c|c|c|c|c|c|}
\hline & & \multicolumn{7}{|c|}{ Land use in $2009 / 2010$} \\
\hline & & Forest & Shrubland & Grassland & Urban & Cropland & Water & Bare soil \\
\hline (i) & Forest & $0.0 \%$ & $24.5 \%$ & $4.0 \%$ & $0.4 \%$ & $2.1 \%$ & $25.2 \%$ & $2.0 \%$ \\
\hline \multirow{5}{*}{$\begin{array}{l}\text { Land use } \\
\text { in } 1989 / 1990\end{array}$} & Shrubland & $75.7 \%$ & $0.0 \%$ & $79.5 \%$ & $4.8 \%$ & $17.1 \%$ & $26.1 \%$ & $37.9 \%$ \\
\hline & Grassland & $16.4 \%$ & $59.8 \%$ & $0.0 \%$ & $72.8 \%$ & $70.8 \%$ & $37.2 \%$ & $0.0 \%$ \\
\hline & Urban & $0.5 \%$ & $1.8 \%$ & $3.5 \%$ & $0.0 \%$ & $8.4 \%$ & $3.0 \%$ & $57.2 \%$ \\
\hline & Cropland & $6.5 \%$ & $12.4 \%$ & $12.8 \%$ & $21.7 \%$ & $0.0 \%$ & $8.5 \%$ & $0.0 \%$ \\
\hline & Water & $0.9 \%$ & $1.4 \%$ & $0.2 \%$ & $0.3 \%$ & $1.6 \%$ & $0.0 \%$ & $2.9 \%$ \\
\hline \multicolumn{2}{|c|}{$\begin{array}{l}\text { (ii) Changed area with } 2009 / 2010 \\
\text { land use as percentage } \\
\text { of the catchment area }\end{array}$} & $8.4 \%$ & $11.9 \%$ & $7.0 \%$ & $6.5 \%$ & $8.2 \%$ & $0.8 \%$ & $0.3 \%$ \\
\hline \multicolumn{2}{|c|}{$\begin{array}{l}\text { (iii) Net change per land use } \\
\text { class between } 1989 / 1990 \text { and } \\
2009 / 2010\end{array}$} & $+4.8 \%$ & $-2.1 \%$ & $-11.9 \%$ & $+5.1 \%$ & $+3.7 \%$ & $+0.3 \%$ & - \\
\hline
\end{tabular}

should not be interpreted as major changes. As indicated before (Fig. 2) the main changes are an increase of urban area and cropland. This is also reflected in the percentage of the catchment area that was changed to cropland $(8.2 \%)$ and to urban area (6.5\%) between 1989/1990 and 2009/2010 (Table 5). On the sub-basin level these changes are more pronounced, with up to $22.3 \%$ of the area changed to cropland in some sub-basins and up to $32.4 \%$ of the area changed to urban area in other sub-basins. For this reason, a focus will be set on the sub-basin level in the following analysis of the impacts of these land use changes on the water resources in the study area.

\subsection{Land use change impacts}

Two $21 \mathrm{yr}$ model runs were performed using the multitemporal land use classifications of 1989/1990 and 2009/2010, respectively. This delta approach does not necessarily provide results that reflect the hydrologic observations of the past $20 \mathrm{yr}$, but illustrates the impacts of the main changes on the hydrologic components (Miller et al., 2002). On the catchment scale the positive and negative impacts cancel each other out, so that differences in the long-term water balance components are smaller than $3 \mathrm{~mm} \mathrm{a}^{-1}$. However, more pronounced changes are discernible on the sub-basin level. Figures 4 and 5 show the percentage change of evapotranspiration (ET) and water yield per sub-basin. The changes in longterm ET range from a decrease of $-8.1 \%\left(-45 \mathrm{~mm} \mathrm{a}^{-1}\right)$ in sub-basin 6 to an increase of $5.9 \%\left(40 \mathrm{~mm} \mathrm{a}^{-1}\right)$ in subbasin 14. A major decrease of long-term mean annual ET is obvious in the eastern part of the catchment $(-0.8 \%$ to $-8.1 \%$ ). Main increases $(>4.5 \%$ ) can be observed in the mid-northern part (sub-basins 2 and 3) and in one small sub-basin (14) in the Western Ghats. In order to relate these changes in ET to the changes in land use, the changes in each land use class for each sub-basin are assessed as the difference between the area under this land use in 2009/2010 and 1989/1990 expressed as percentage of the sub-basin area. The percentages of changed cropland and urban area, which were previously identified as the major land use changes in the catchment, are shown for each sub-basin in Figs. 4 and 5. As indicated by significant correlations ( $p$ value $<0.001$ ) and linear regression analysis (Fig. 6), the changes in ET can be attributed to changes of cropland $\left(R^{2}=0.46\right)$ and urban land $\left(R^{2}=0.48\right)$. Figure 6 shows that cropland and ET are positively correlated, whereas urban land and ET have a negative correlation. It is clearly shown that the change of urban land can explain the decrease of ET but not its increase (Fig. 6b). The other land uses do not show a correlation with ET at the $0.1 \%$ significance level.

Figure 5 shows the impact of land use changes on runoff as a percentage change of the water yield within each subbasin. In this context, water yield is the net amount of water provided by the sub-basin that contributes to stream flow (SWAT output parameter WYLD). This definition excludes the amount of water that enters a sub-basin as stream flow from an upstream sub-basin. Changes in long-term mean annual water yield range from an increase of $0.03 \%\left(1 \mathrm{~mm} \mathrm{a}^{-1}\right)$ in sub-basin 14 to an increase of $7.6 \%\left(29 \mathrm{~mm} \mathrm{a}^{-1}\right)$ in subbasin 17. The most pronounced increase in mean annual water yield $(>3.5 \%)$ was found in the eastern sub-basins $(4$, $5,6,12$, and 17). The increase in water yield was less pronounced in the adjacent sub-basins towards the west. No increase or only slight increases were detected in the western part of the catchment. The major driver of the increase in water yield is the change of urban area $\left(R^{2}=0.63\right)$. The 


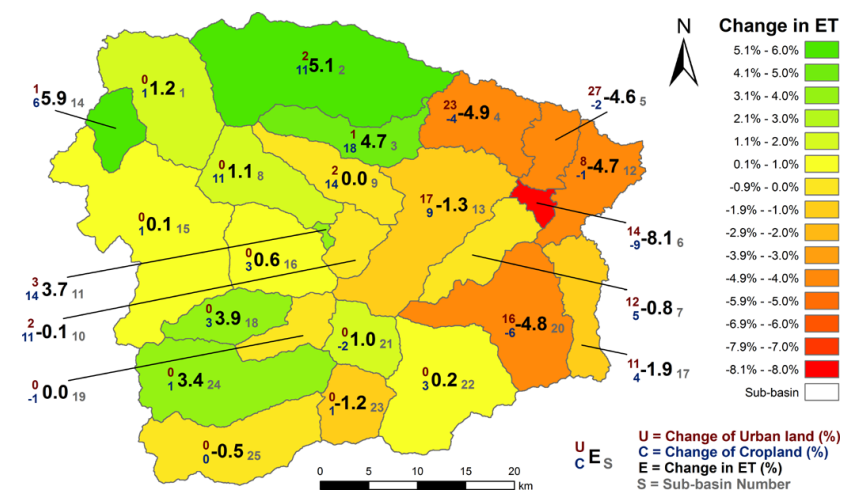

Fig. 4. Change in evapotranspiration (ET) per sub-basin and changed cropland and urban area as percentage of sub-basin area between 1989/1990 and 2009/2010.

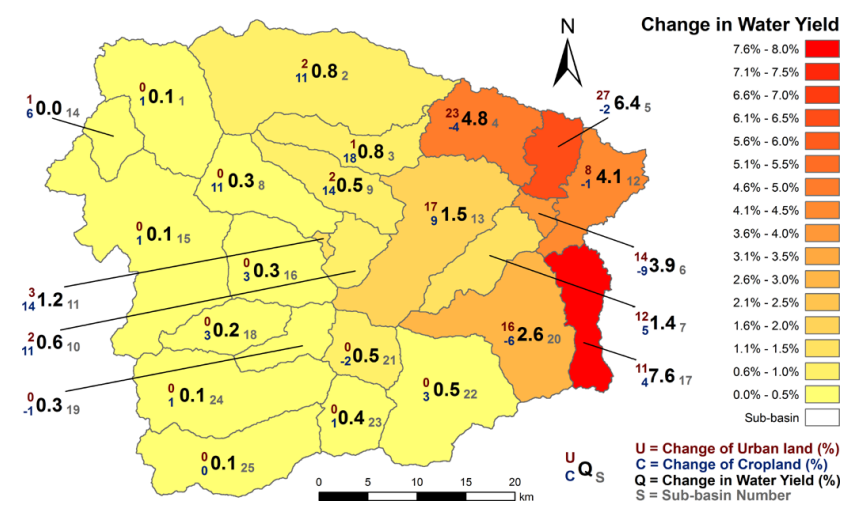

Fig. 5. Change in water yield per sub-basin and changed cropland and urban area as percentage of sub-basin area between 1989/1990 and 2009/2010.

positive correlation (Fig. 7a) of change in urban land and in water yield is highly significant ( $p$ value $<0.001$ ). Correlations with other land use changes did not yield a relationship at this significance level. However, since mainly grassland is converted to urban land, the change in grassland shows a negative correlation with the change in water yield, which is significant at the $0.5 \%$ significance level. The sub-basin size does not yield a significant relationship with the increase in water yield (Fig. 7b). Obviously, land use changes are more important than sub-basin size with regard to the impact on the water yield. However, Fig. $7 \mathrm{~b}$ indicates that the potential response to land use changes is larger in smaller sub-basins, as the range of the impacts on water yield is larger for the sub-basins smaller than $100 \mathrm{~km}^{2}$, and decreases with an increase of the size of the sub-basin.

The shown relationships are reflected in the spatial patterns of the changes in ET (Fig. 4) and water yield (Fig. 5). In the eastern part of the catchment an increase of urban area can be observed, whereas cropland decreases or increases only slightly (Figs. 3 and 4). In these eastern sub-basins water yield increases (Fig. 5) whereas ET decreases (Fig. 4).
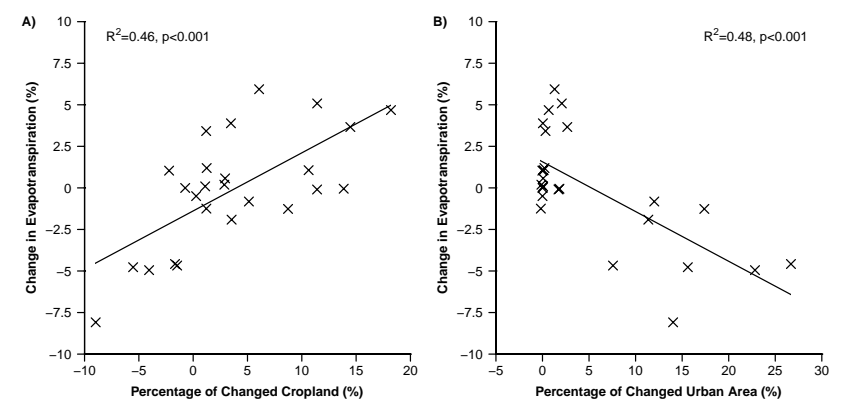

Fig. 6. Change in evapotranspiration explained by the percentage of changed cropland (A) and changed urban area (B) in each subbasin.
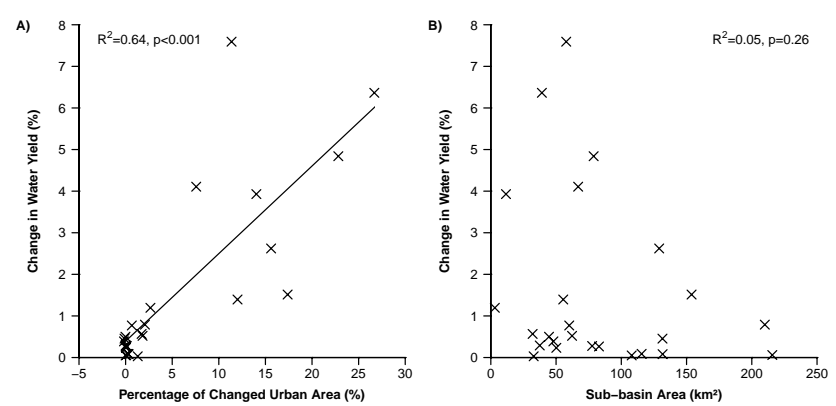

Fig. 7. Change in water yield and its relation to the percentage of changed urban area in each sub-basin (A) and to the size of the subbasins (B).

Larger increases of cropland (9\% to $18 \%$ of the sub-basin area) are apparent in the mid-northern part of the catchment, which often result in increased ET in these sub-basins. Water yield increases slightly in these sub-basins. The increase of ET can be attributed to the irrigation of crops in dry season. Between December and May increased irrigation water use and water withdrawal from the rivers can be observed in sub-basins with an increase of irrigated cropland (e.g., subbasin 2). Thus ET increases in these sub-basins. However, as river water is used, this does not necessarily have a negative impact on the water yield within the sub-basin itself. On the contrary, irrigation water that is taken from the river contributes to a slight increase of the water yield within the subbasin. For sub-basins that are downstream of other sub-basins and experience an increase in cropland, this explains why ET and runoff increase at the same time (e.g., sub-basins 2, 11, 16). However, some sub-basins that do not have inflow from upstream sub-basins also show an increase in ET and water yield (e.g., sub-basins 1, 18, 24). This is because of a decrease of the storage in these sub-basins between 1989/1990 and 2009/2010.

In some sub-basins the opposing effects of an increase in water yield (due to an increase of urban area) and an increase in ET (due to an increase in cropland) cancel each other out (e.g., sub-basins 7, 13). However in sub-basin 6, where the 
percentage of changed urban area is positive and the percentage of changed cropland is negative, both land use changes lead to a decrease of ET, and result in the largest decrease of ET on the sub-basin level.

\section{Discussion}

The produced land use classifications have an agreeable accuracy and hence the major land use changes in the study area were accurately identified. However, unlikely changes from urban area to cropland have been observed in the present study (Table 5). These may result from (a) a misclassification of cropland in the 2009/2010 classification or (b) misclassified urban area in the 1989/1990 classification. However, these comprise only $8.4 \%$ of the catchment area that was changed to cropland ( $8.2 \%$ of the catchment, Table 5) and indicate therefore a small, acceptable uncertainty of the method.

Similarly, the changes within the semi-natural class between forest, shrubland, and grassland may be attributed to the applied methodology. The three satellite images for the historic land use classifications 1989/1990 and 2000/2001 were not taken at the same time of the year (Table 3), due to the limited availability of cloud-free scenes. Classification differences can be attributed to different phenological states of the plants. Although multitemporal approaches generally help to minimize these problems (e.g., Oetter et al., 2000; Wolter et al., 1995; Yuan et al., 2005), it is obvious that the different dates of the satellite had an impact on the classification. This is particularly true for the semi-natural classes which depend on the natural water availability that constantly declines during dry season. As the month of the second scene in the 1989/1990 and 2000/2001 classification differ (December 1989, January 2001), the time gap probably had an impact on the classification of the shrubland class, which accounted for $28 \%$ of the catchment area in 1989/1990 and only $22 \%$ in $2000 / 2001$.

For the 2009/2010 classification, a different methodology was applied to produce a multitemporal classification, as the majority approach is not applicable when combining two land use classifications. Therefore, different rules were applied to derive the multitemporal land use classes. With regard to the semi-natural classes, these rules gave priority to the class with a higher percentage of trees. This might have led to a higher percentage of forest and a smaller percentage of grassland in the 2009/2010 classification, as compared to the historic land use classifications. The seminatural classes are a continuum and therefore generally hard to distinguish. With the data that was available to this study, it seems unlikely to derive very accurate estimates of intraclass changes. However, the general decrease of semi-natural land is a reliable result of this study.

The location of the main land use changes (increase of urban area and increase of cropland) in the catchment suggests that urbanization causes a relocation of cropland from the former city fringes to the nearest possible location. An expansion of urban area was mainly found at the fringes and northwest of the city of Pune (Fig. 3). In these areas cropland either decreased or increased only slightly (Fig. 4). The pronounced increase of cropland in the mid-northern part of the catchment (Figs. 3 and 4) might be in part a result of the urbanization process. As cropland is converted to urban area on the city fringes, arable grassland in the valleys of the Western Ghats is converted to cropland. It is reasonable that this relocation of cropland can be observed towards the west, as water availability increases there. The fact that cropland mainly increases in the northern part of the catchment may be due to better accessibility (e.g., highway) and a higher potential of arable land. The valleys in the southern part of the catchment are either covered with reservoirs or are very small and therefore not suitable for a major conversion to cropland.

The increase of the water yield and decrease in evapotranspiration due to an increase of built-up area (Figs. 6b and 7a) was also found in other studies (e.g., Im et al., 2009; Wijesekara et al., 2012). However, these impacts on water yield and evapotranspiration appear to be not very pronounced $(<8.1 \%)$ as compared to the rate of urbanization. This is possibly due to the monsoon-dominated rainfall in the catchment. Heavy rains rapidly exceed the infiltration capacity of the soil and thus lead to Hortonian surface runoff. Therefore runoff on non-paved surfaces differs only slightly from runoff on paved surfaces, which is indicated by our results. Moreover, Du et al. (2012) found that the impact of urbanization on annual runoff is smaller as compared to its impact on floods. In particular, smaller floods are more affected than larger floods by an increase of impervious area (Du et al., 2012).

It has to be noted that a part of the increase of the water yield caused by urbanization results from conversion to highdensity urban area. High and medium urban density were not distinguished in the $1989 / 1990$ classification, as the total built-up land was significantly smaller as in 2009/2010. Hence, the observed change in water yield is in part a consequence of the higher level of detail of the 2009/2010 land use classification. In order to assess the impact of the distinguished high-density area, the model was run for the land use of 2009/2010 combining the two urban land use classes to one medium-density class. A comparison with the previous results indicates that the higher urban density setup had a pronounced impact in sub-basin 17, which includes the inner city of Pune, and where half of the percentage change in water yield $(3.9 \%)$ can be attributed to the high urban density setup. However, in the majority of the sub-basins (20) no effect or only a small effect on the water yield (accounting for less than $0.15 \%$ ), and only a slight effect in the sub-basins 4 , 5,6 , and 20 (accounting for $1.0 \%, 0.9 \%, 0.3 \%$ and $0.5 \%$, respectively) can be observed. It should be taken into consideration that urbanization can include an increased sealing of surfaces, which is possibly overestimated in the case of 
sub-basin 17, but seems reasonable for the other sub-basins. The current assessment provides evidence that this process leads to an increase of the water yield.

It is well known that impacts on the annual water balance of a catchment are relatively small due to compensating effects in a catchment (e.g., Fohrer et al., 2001). In a large-scale study on the Meuse River basin, Ashagrie et al. (2006) conclude that the overall impact of land use changes was too small to be detected. Wilk and Hughes (2002) argue that the complexity of large river basins could mask many of the impacts of land use changes that have been identified on smaller scales. Similarly, the FAO (2002) suggests that impacts of land use on hydrology can be studied best in small basins $\left(<1000 \mathrm{~km}^{2}\right)$. In this study, this effect is underlined by the fact that impacts on the water balance cancel out on the catchment scale, whereas they are observable on the sub-basin scale, and are more pronounced in the smaller sub-basins (e.g., impact on ET in sub-basins 6, 11, 14, Fig. 4; higher impacts on the water yield in smaller sub-basins, Fig. 7b).

\section{Conclusions}

Our results show that by using SWAT together with generally available data, land use change impacts upon water fluxes can be successfully quantified in data-scarce regions. The land use changes found in our study area, in particular urbanization and the increase of agricultural area, are typical for many regions in India. Our analysis indicates that an increase of agricultural area leads to an exacerbation of the imbalance of water availability and demand in dry season due to increased consumption of irrigation water, whereas urbanization results in more runoff during rainy season due to the increase of paved surface area. Thus in monsoon regions, urbanization and increase in agricultural areas aggravate the imbalance between seasonal water availability and water demand.

It was found that multitemporal land use classifications derived from multispectral satellite data provide suitable data to assess past land use changes. In the present study, urbanization was identified as the main driver of change in the study area. Urbanization has resulted in a shift of cropland towards the west, specifically into the valleys of the Western Ghats. As it is likely that the rapid growth of the city of Pune will progress, it can be expected that further urbanization will probably reduce the cropland in the study area, as a further shift towards the west is not possible (deforestation of the biodiversity-rich Western Ghats is unlikely). Thus, an increased demand for food due to population growth and a decreased supply of food due to decreased cropland will be a negative consequence of this development.

Our results regarding the water balance indicate that ongoing urbanization will result in less evapotranspiration and more runoff. In the mean annual water balance, this effect was balanced by an increase of cropland in some areas of the

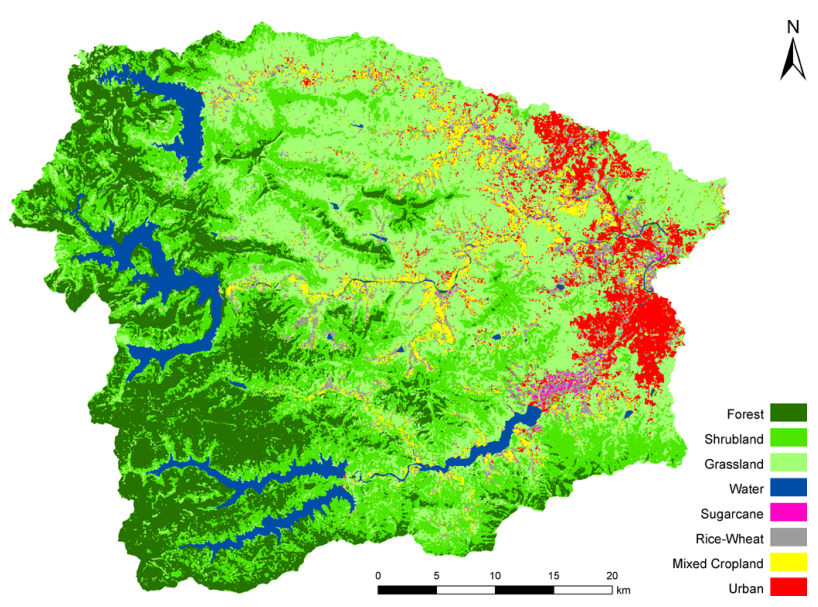

Fig. A1. Multitemporal land use classification 1989/1990.

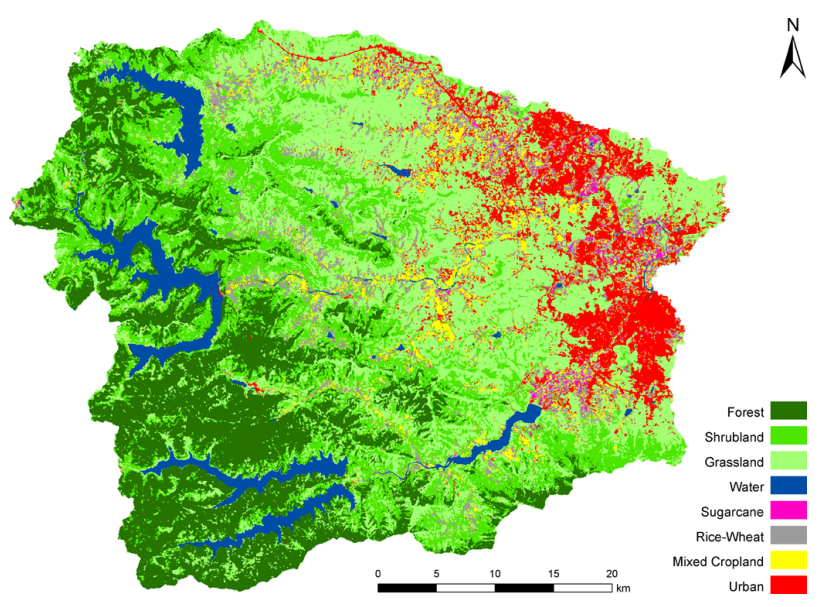

Fig. A2. Multitemporal land use classification 2000/2001.

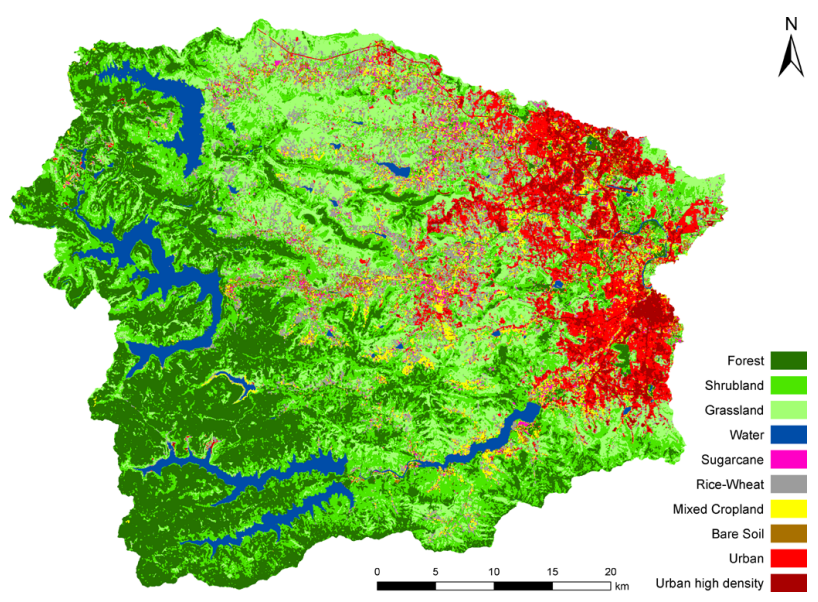

Fig. A3. Multitemporal land use classification 2009/2010. 
catchment. However, the mean seasonal variation of runoff was changed, as urbanization resulted in more runoff in rainy season, whereas increased irrigation water withdrawal from the rivers led to less runoff in dry season. This change in runoff potentially affects the downstream population, irrigation agriculture, and industries, all of whom rely heavily on the water supplied from the Mula and Mutha Rivers catchment. The loss of these resources for downstream water users could be prevented by storing the increased runoff in downstream reservoirs (e.g., in the Ujjani dam). However, water users between Pune and the Ujjani dam (about $100 \mathrm{~km}$ distance) would be affected by a decrease of runoff from the catchment in dry season. Beyond these implications for water quantity, further urbanization will obviously have negative effects on water quality (e.g., due to increased sewage water and industrial waste water).

The increase of the water yield was relatively moderate on the sub-basin level. On the one hand, further urbanization towards the west may lead to more pronounced impacts (e.g., higher peak discharges, flooding) as the western part of the catchment receives significantly more precipitation than the eastern part. On the other hand, these impacts might be less pronounced as heavy rains rapidly exceed the infiltration capacity of the soil and thus seal the surface, resulting in the same effect on runoff as paved areas. Possibly, as indicated by Du et al. (2012), smaller floods may be affected by these changes. An analysis of future land use scenarios and their impacts on the water resources would shed light on the impacts of further urbanization in the Western Ghats.

\section{Appendix A}

\section{Land use classifications}

Multitemporal land use classifications of 1989/1990, 2000/2001, and 2009/2010. See Figs. A1, A2, and A3, respectively.

Acknowledgements. We gratefully acknowledge support by a grant from the German National Academic Foundation. We are grateful to IMD Pune, Water Resources Department Nashik, Khadakwasla Irrigation Division Pune, Groundwater Department Pune, Department of Agriculture Pune, and NRSC Hyderabad for supplying environmental data, cooperation and enlightened discussions. Moreover, we acknowledge the supply of ASTER data by the USGS Land Processes Distributed Active Archive Center. Special thanks go to Wayne Dunn for proofreading the manuscript and to the students from the Institute of Environment Education \& Research at Bharati Vidyapeeth University Pune for assistance with the field measurements. The authors thank the editor and the three anonymous reviewers for their helpful comments.

Edited by: D. Mazvimavi

\section{References}

Arnold, J. G., Srinivasan, R., Muttiah, R. S., and Williams, J. R.: Large area hydrologic modeling and assessment - Part 1: Model development, J. Am. Water Resour. As., 34, 73-89, 1998.

Ashagrie, A. G., de Laat, P. J., de Wit, M. J., Tu, M., and Uhlenbrook, S.: Detecting the influence of land use changes on discharges and floods in the Meuse River Basin - the predictive power of a ninety-year rainfall-runoff relation?, Hydrol. Earth Syst. Sci., 10, 691-701, doi:10.5194/hess-10-691-2006, 2006.

Barthel, R., Reichenau, T. G., Krimly, T., Dabbert, S., Schneider, K., Hennicker, R., and Mauser, W.: Integrated modeling of global change impacts on agriculture and groundwater resources, Water Resour. Manag., 26, 1929-1951, 2012.

Behera, S. and Panda, R. K.: Evaluation of management alternatives for an agricultural watershed in a sub-humid subtropical region using a physical process based model, Agr. Ecosyst. Environ., 113, 62-72, 2006.

Bergström, S. and Forsman, A.: Development of a conceptual deterministic rainfall-runoff model, Nord. Hydrol., 4, 147-170, 1973.

Chauhan, H. B. and Nayak, S.: Land use/land cover changes near Hazira Region, Gujarat using remote sensing satellite data, J. Indian Soc. Remote Sens., 33, 413-420, 2005.

DeFries, R. and Eshleman, K. N.: Land-use change and hydrologic processes: a major focus for the future, Hydrol. Process., 18, 2183-2186, 2004.

Du, J., Qian, L., Rui, H., Zuo, T., Zheng, D., Xu, Y., and Xu, C.Y.: Assessing the effects of urbanization on annual runoff and flood events using an integrated hydrological modeling system for Qinhuai River basin, China, J. Hydrol., 464-465, 127-139, 2012.

Du, Y., Chang, C.-I., Ren, H., Chang, C.-C., Jensen, J. O., and D'Amico, F. M.: New hyperspectral discrimination measure for spectral characterization, Opt. Eng., 43, 1777-1786, 2004.

Fohrer, N., Haverkamp, S., Eckhardt, K., and Frede, H.-G.: Hydrologic response to land use changes on the catchment scale, Phys. Chem. Earth Pt. B, 26, 577-582, 2001.

Food and Agriculture Organization of the United Nations (FAO): Land-water linkages in rural catchments, Land and water bulletin 9, FAO, Rome, 2002.

Food and Agriculture Organization of the United Nations (FAO): Digital Soil Map of the World and Derived Soil Properties, FAO, Rome, 2003.

Gadgil, A.: Rainfall characteristics of Maharashtra, in: Geography of Maharashtra, edited by: Diddee, J., Jog, S. R., Kale, V. S., and Datye, V. S., Rawat Publications, Jaipur, 89-102, 2002.

Garg, K. K., Bharati, L., Gaur, A., George, B., Acharya, S., Jella, K., and Narasimhan, B.: Spatial mapping of agricultural water productivity using the SWAT model in Upper Bhima catchment, India, Irrig. Drain., 61, 60-79, 2012a.

Garg, K. K., Karlberg, L., Barron, J., Wani, S. P., and Rockstrom, J.: Assessing impacts of agricultural water interventions in the Kothapally watershed, Southern India, Hydrol. Process., 26, 387-404, 2012b.

Garg, K. K., Wani, S. P., Barron, J., Karlberg, L., and Rockstrom, J.: Up-scaling potential impacts on water flows from agricultural water interventions: opportunities and trade-offs in the Osman Sagar catchment, Musi sub-basin, India, Hydrol. Process., online first, doi:10.1002/hyp.9516, 2012c. 
Gassman, P. W., Reyes, M., Green, C. H., and Arnold, J. G.: The Soil and Water Assessment Tool: Historical development, applications, and future directions, T. ASABE, 50, 1211-1250, 2007.

Ghaffari, G., Keesstra, S., Ghodousi, J., and Ahmadi, H.: SWATsimulated hydrological impact of land-use change in the Zanjanrood basin, Northwest Iran, Hydrol. Process., 24, 892-903, 2010.

Government of India: Population Growth - Levels and Trends, in: Census of India 2011, Provisional Population Totals, Paper 1 of 2011: Maharashtra, available at: http://www.censusindia.gov.in/2011-prov-results/data_files/ maharastra/7-\%20Chapter\%20-\%204.pdf (last access: 11 October 2012), 2011.

Gunnell, Y.: Relief and climate in South Asia: The influence of the Western Ghats on the current climate pattern of peninsular India, Int. J. Climatol., 17, 1169-1182, 1997.

Hansen, M., DeFries, R., Townshend, J. R. G., and Sohlberg, R.: UMD Global Land Cover Classification, Department of Geography, University of Maryland, College Park, Maryland, 1998.

Huisman, J. A., Breuer, L., Bormann, H., Bronstert, A., Croke, B. F. W., Frede, H.-G., Gräff, T., Hubrechts, L., Jakeman, A. J., Kite, G., Lanini, J., Leavesley, G., Lettenmaier, D. P., Lindström, G., Seibert, J., Sivapalan, M., Viney, N. R., and Willems, P.: Assessing the impact of land use change on hydrology by ensemble modeling (LUCHEM) III: Scenario analysis, Adv. Water Resour., 32, 159-170, 2009.

Im, S., Kim, H., Kim, C., and Jang, C.: Assessing the impacts of land use changes on watershed hydrology using MIKE SHE, Environ. Geol., 57, 231-239, 2009.

Immerzeel, W. W., Gaur, A., and Zwart, S. J.: Integrating remote sensing and a process-based hydrological model to evaluate water use and productivity in a south Indian catchment, Agr. Water Manage., 95, 11-24, 2008.

Jayakumar, S. and Arockiasamy, D.: Land use/land cover mapping and change detection in part of Eastern Ghats of Tamil Nadu using remote sensing and GIS, J. Indian Soc. Remote Sens., 31, 251-260, 2003.

Jensen, J. R.: Remote Sensing of the Environment: An Earth Resource Perspective, 2nd Edn., Pearson Prentice Hall, Upper Saddle River, New Jersey, 2007.

Jha, C. S., Dutt, C. B. S., and Bawa, K. S.: Deforestation and land use changes in Western Ghats, India, Curr. Sci. India, 79, 231238, 2000 .

Khan, H. H., Khan, A., Ahmed, S., and Perrin, J.: GIS-based impact assessment of land-use changes on groundwater quality: Study from a rapidly urbanizing region of South India, Environ. Earth Sci., 63, 1289-1302, 2011.

Kirchner, J. W.: Getting the right answers for the right reasons: Linking measurements, analyses, and models to advance the science of hydrology, Water Resour. Res., 42, W03S04, doi:10.1029/2005WR004362, 2006.

Klöcking, B. and Haberlandt, U.: Impact of land use changes on water dynamics - a case study in temperate meso and macroscale river basins, Phys. Chem. Earth, 27, 619-629, 2002.

Legesse, D., Vallet-Coulomb, C., and Gasse, F.: Hydrological response of a catchment to climate and land use changes in Tropical Africa: case study South Central Ethiopia, J. Hydrol., 275, 67-85, 2003.

Li, Z., Liu, W., Zhang, X., and Zheng, F.: Impacts of land use change and climate variability on hydrology in an agricultural catchment on the Loess Plateau of China, J. Hydrol., 377, 35-42, 2009.

Mango, L. M., Melesse, A. M., McClain, M. E., Gann, D., and Setegn, S. G.: Land use and climate change impacts on the hydrology of the upper Mara River Basin, Kenya: results of a modeling study to support better resource management, Hydrol. Earth Syst. Sci., 15, 2245-2258, doi:10.5194/hess-15-22452011, 2011.

Matthew, M. W., Adler-Golden, S. M., Berk, A., Richtsmeier, S. C., Levine, R. Y., Bernstein, L. S., Acharya, P. K., Anderson, G. P., Felde, G. W., Hoke, M. P., Ratkowski, A., Burke, H.-H., Kaiser, R. D., and Miller, D. P.: Status of atmospheric correction using a MODTRAN4-based algorithm, SPIE Proceedings 4049, Algorithms for Multispectral, Hyperspectral, and Ultraspectral Imagery VI., Orlando, Florida, 24 April 2000, 199-207, 2000.

Miller, S. N., Kepner, W. G., Mehaffey, M. H., Hernandez, M., Miller, R. C., Goodrich, D. C., Devonald, K. K., Heggem, D. T., and Miller, W. P.: Integrating landscape assessment and hydrologic modeling for land cover change analysis, J. Am. Water Resour. As., 38, 915-929, 2002.

Mishra, A., Kar, S., and Singh, V. P.: Prioritizing structural management by quantifying the effect of land use and land cover on watershed runoff and sediment yield, Water Resour. Manag., 21, 1899-1913, 2007.

Nash, J. E. and Sutcliffe, J. V.: River flow forecasting through conceptual models: Part I. A discussion of principles, J. Hydrol., 10, 282-290, 1970.

Ndomba, P., Mtalo, F., and Killingtveit, A.: SWAT model application in a data scarce tropical complex catchment in Tanzania, Phys. Chem. Earth, 33, 626-632, 2008.

Neitsch, S. L., Arnold, J. G., Kiniry, J. R., Srinivasan, R., and Williams, J. R.: Soil and Water Assessment Tool: Input/Output File Documentation, Version 2009, Texas Water Resources Institute, Texas A\&M University, College Station, Texas, 2010.

Niehoff, D., Fritsch, U., and Bronstert, A.: Land-use impacts on storm-runoff generation: scenarios of land-use change and simulation of hydrological response in a meso-scale catchment in SW-Germany, J. Hydrol., 267, 80-93, 2002.

Oetter, D. R., Cohen, W. B., Berterretche, M., Maiersperger, T. K., and Kennedy, R. E.: Land cover mapping in an agricultural setting using multiseasonal Thematic Mapper data, Remote Sens. Environ., 76, 139-155, 2000.

Peiman, R.: Pre-classification and post-classification changedetection techniques to monitor land-cover and land-use change using multi-temporal Landsat imagery: a case study on Pisa Province in Italy, Int. J. Remote Sens., 32, 4365-4381, 2011.

Ramesh, R.: Effects of land-use change on groundwater quality in a coastal habitat of South India, IAHS-AISH P., 269, 161-166, 2001.

Refsgaard, J. C. and Storm, B.: MIKE SHE, in: Computer Models of Watershed Hydrology, edited by: Singh, V. P., Water Resources Publications, Highlands Ranch, Colorado, 809-846, 1995.

Saha, A. K., Arora, M. K., Csaplovics, E., and Gupta, R. P.: Land Cover Classification Using IRS LISS III Image and DEM in a Rugged Terrain: A Case Study in Himalayas, Geocarto Int., 20, 33-40, 2005.

Schulla, J.: Hydrologische Modellierung von Flussgebieten zur Abschätzung der Folgen von Klimaänderungen, Zürcher Geographische Schriften, 69, Geographisches Institut ETH, Zürich, 
1997.

Seeber, C., Hartmann, H., Xiang, W., and King, L.: Land use change and causes in the Xiangxi catchment, Three Gorges Area derived from multispectral data, J. Earth Sci., 21, 846-855, 2010.

Sharma, E., Bhuchar, S., Xing, M., and Kothyari, B. P.: Land use change and its impact on hydro-ecological linkages in Himalayan watersheds, Trop. Ecol., 48, 151-161, 2007.

Sharma, T., Satya Kiran, P. V., Singh, T. P., Trivedi, A. V., and Navalgund, R. R.: Hydrologic response of a watershed to land use changes: A remote sensing and GIS approach, Int. J. Remote Sens., 22, 2095-2108, 2001.

Singh, R. B.: Impact of land-use change on groundwater in the Punjab-Haryana plains, India, IAHS-AISH P., 269, 117-122, 2001.

Stehr, A., Debels, P., Romero, F., and Alcayaga, H.: Hydrological modelling with SWAT under conditions of limited data availability: evaluation of results from a Chilean case study, Hydrolog. Sci. J., 53, 588-601, 2008.

Stonestrom, D. A., Scanlon, B. R., and Zhang, L.: Introduction to special section on Impacts of Land Use Change on Water Resources, Water Resour. Res., 45, W00A00, doi:10.1029/2009WR007937, 2009.

Story, M. and Congalton, R. G.: Accuracy assessment: A user's perspective, Photogramm. Eng. Remote Sens., 52, 397-399, 1986.

Villarreal, M. L., Norman, L. M., Wallace, C. S. A., and van Riper III, C.: A multitemporal (1979-2009) land-use/land-cover dataset of the binational Santa Cruz Watershed, Open-File Report 2011-1131, US Geological Survey, Reston, Virginia, 2011.
Wagner, P. D., Kumar, S., Fiener, P., and Schneider, K.: Hydrological modeling with SWAT in a monsoon-driven environment experience from the Western Ghats, India, T. ASABE 54, 17831790, 2011.

Wagner, P. D., Fiener, P., Wilken, F., Kumar, S., and Schneider, K.: Comparison and evaluation of spatial interpolation schemes for daily rainfall in data scarce regions, J. Hydrol., 464-465, 388400, 2012.

Wijesekara, G. N., Gupta, A., Valeo, C., Hasbani, J.-G., Qiao, Y., Delaney, P., and Marceau, D. J.: Assessing the impact of future land-use changes on hydrological processes in the Elbow River watershed in southern Alberta, Canada, J. Hydrol., 412413, 220-232, 2012.

Wilk, J. and Hughes, D. A.: Simulating the impacts of land-use and climate change on water resource availability for a large south Indian catchment, Hydrolog. Sci. J., 47, 19-30, 2002.

Wolter, P. T., Mladenoff, D. J., Host, G. E., and Crow, T. R.: Improved forest classification in the Northern Lake States using multi-temporal Landsat imagery, Photogramm. Eng. Remote Sens., 61, 1129-1143, 1995.

Yuan, F., Sawaya, K. E., Loeffelholz, B. C., and Bauer, M. E.: Land cover classification and change analysis of the Twin Cities (Minnesota) Metropolitan Area by multitemporal Landsat remote sensing, Remote Sens. Environ., 98, 317-328, 2005. 